\title{
Effects of Production System (Free-Range and Intensive) and Carcass Parts (Breast and Thigh) on Nutrient and Fatty Acid Composition of Guinea Fowl, Pheasant and Partridges
}

\begin{tabular}{|c|c|}
\hline \multicolumn{2}{|c|}{$\begin{array}{l}\text { Mehmet Akif Boz }{ }^{\mathbf{1}, \mathbf{a}, *}, \text { Musa Sarıca, }{ }^{\mathbf{2}, \mathbf{b}} \text {, Umut Sami Yamak }{ }^{\mathbf{2 , c}}, \mathbf{F a t i h} \mathbf{O ̈ z}^{\mathbf{3}, \mathbf{d}} \\
{ }^{1} \text { Department of Animal Science, Agricultural Faculty, Bozok University, } 66200 \text { Yozgat, Turkey } \\
{ }^{2} \text { Department of Animal Science, Agricultural Faculty, Ondokuz Mayis University, } 55139 \text { Atakum, Samsun, Turkey } \\
{ }^{3} \text { Department of Food Engineering, Agricultural Faculty, Ataturk University, } 25030 \text { Erzurum, Turkey } \\
{ }^{*} \text { Corresponding author }\end{array}$} \\
\hline A R T I C LE INFO & A B S T R A C T \\
\hline $\begin{array}{l}\text { Keywords: } \\
\text { Partridge } \\
\text { Pheasant } \\
\text { Guinea fowl } \\
\text { Dry matter } \\
\text { Fatty acids }\end{array}$ & $\begin{array}{l}\text { This research was carried out to determine the composition of nutrients and fatty acids in the } \\
\text { breast and thigh meat of guinea fowls, partridges and pheasants reared in free-range and intensive } \\
\text { systems for } 16 \text { weeks, Partridge, pheasant and guinea fowls reared in free-range and intensive } \\
\text { systems (male-female mixed) were slaughtered at } 16 \text { weeks of age and the skinless breast and } \\
\text { thigh samples were analysed., Crude fat ratio, linoleic acid, linolenic acid and cis-11-eicosenoic } \\
\text { acid in partridge, myristic acid in guinea fowl, cis- } 4,7,10,13,16,19 \text {-docosahexaenoic acid (DHA) in } \\
\text { pheasant, stearic acid and erucic acid in pheasant and guinea fowl, and oleic acid was higher in } \\
\text { partridge and pheasant meat, The effect of the production system on the content of nutrients and } \\
\text { fatty acids was insignificant. While dry matter, crude protein, myristic acid, palmitic acid and } \\
\text { stearic acid were higher in breast meat; oleic acid, linoleic acid, linolenic acid, erucic acid and cis- } \\
4,7,10,13,16,19 \text {-docosahexaenoic acid (DHA) ratios found higher in thigh meat, As a result, while } \\
\text { the content of nutrients and fatty acids varied significantly depending on the species and the } \\
\text { carcass parts, the effect of the production system was found insignificant. }\end{array}$ \\
\hline
\end{tabular}

Tavukçuluk Araştırma Dergisi 17(2): 102-106, 2020

\section{Beç Tavuğu, Sülün ve Kekliklerde Yetiştirme Sistemi (Kapalı ve Serbest Gezinmeli) ve Karkas Parçalarının (But ve Göğüs) Besin Madde ve Yağ Asitleri Kompozisyonuna Etkileri}

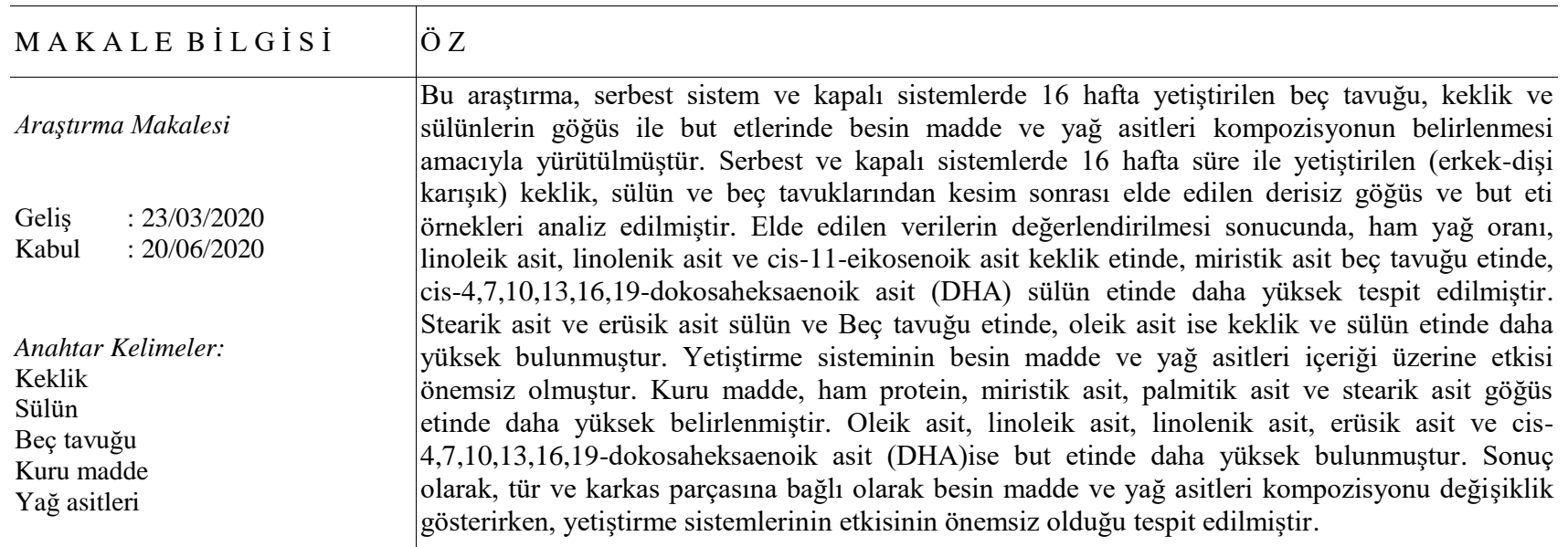




\section{Giriş}

ABD, Uzakdoğu ülkeleri ve Avrupa başta olmak üzere tüm dünyada alternatif kanatlı yetiştiriciliği gittikçe önem kazanmaktadır. Bu kanatlı türleri; değişik lezzet ve kaliteli et ihtiyacına cevap verebilmek, özel avlakların tesisi ile av turizmine gerekli sayıda hayvanı karşılayarak döviz girdisi sağlayabilmek ve koruma kapsamındaki alanlarda doğal dengenin bir parçası olarak önemlerini gittikçe arttırmaktadır. Bununla birlikte son yıllarda hızla gelişen ıslah çalışmaları ve yetiştirme sistemlerindeki gelişmeler bu türlerin entansif ve yarı entansif şartlarda üretilebileceğini göstermiştir (Uçar, 2014). Ülkemizde de keklik, sülün ve beç tavukları gibi farklı tür kanatlı hayvanların üretilerek değerlendirilmesi mümkündür. $\mathrm{Bu}$ hayvanların olumsuz koşullara adaptasyonu iyi olup verim, üreme ve hastalıklara karşı dayanıklı olmaları 1slah materyali veya gen kaynağ 1 olarak kullanılabileceklerini göstermektedir (Sarıca ve ark., 2003; Uçar, 2014; Yıldırım, 2009).

Son ylllarda tavuk etine ilaveten diğer kanatlı etlerinin üretim ve tüketimi artış göstermektedir. Tüketiciler, bu kanatlılardan elde edilen ürünlerde lezzet, tekstür ve rengin tavuk ve hindi etlerine göre farklılığını ifade etmekte ve bunları etin total kalitesi olarak ifade etmektedirler (Alva ve ark., 2005). Etin kimyasal bileşimi et kalitesinin temel bileşenleri olarak belirlemekte ve protein, yağ, kül ve su analizleri yapılmaktadır (Du ve ark., 2002; Yetişir ve ark., 2008). Son yıllarda etteki yağı ve yağ asitleri bileşiminin insan sağlığı açısından önemli olduğu bildirilmektedir (Wood ve ark., 2008).

Et kalitesi genetik ve çevre faktörlerinden etkilenen ve türler arasında ve içerisinde geniş varyasyon gösterebilen karmaşık bir özelliktir (Castellini ve ark., 2002; Yamak ve ark., 2016). Kanatlllarda et kalite özellikleri genetik faktörler, yetiştirme sistemi, bölge, yaş, cinsiyet, besleme, kesim süreci, karkas parçaları gibi birçok faktöre göre değişebilmektedir (Boz ve ark., 2017; Sarıca ve ark., 1999; Solokowicz, 2016). Et kalitesi ile ilgili çalışmalar sülün, beç tavuğu ve keklik türlerinde etlik piliç, hindi, ördek ve kaz gibi kanatlı türlerine göre oldukça sinırlıdır. Ülkemiz şartlarında bu kanatlıların et kalitesi üzerinde yapılacak araştırmalardan elde edilen bilgiler pratik yetiştiricilikte üretim etkinliğini arttıracaktır. Bu çalışmada serbest ve kapalı sistemde 16 hafta süreyle yetiştirilen keklik, beç tavuğu ve sülünlerin göğüs ile but etinde besin madde ve yağ asitleri kompozisyonu belirlenmiştir.

\section{Materyal ve Yöntem}

Araştırmanın materyali Ondokuz Mayıs Üniversitesi Ziraat Fakültesi Araştırma Çiftliği'nde yetiştirilen keklik (A, Chukar), sülün (Phasianus colchicus) ve beç tavuklarından (Numida meleagris) elde edilmiştir.

Serbest ve kapalı sistemlerde 16 hafta yetiştirilen (erkek-dişi karışık) keklik, sülün ve beç tavuklarından rastgele seçilen erkek ve dişilerden 2'şer adet hayvan kesilmiştir. Kesim sonrası elde edilen derisiz göğüs ve but eti örneklerinden araştırmada üzerinde durulan her faktörü temsil edecek 2'şer örnek alınmıştır. Kesim sonrası göğüs ve but etine ait örnekler $-18 /-22^{\circ} \mathrm{C}^{\prime} \mathrm{de}$ analiz edilinceye kadar derin dondurucuda muhafaza edilmiştir. Örneklerin besin madde kompozisyonunun (kuru madde, ham protein, ham yağ, ham kül) belirlenmesinde Gökalp ve ark, (2010)'nın yöntemi kullanılmıştır. Yağ asidi metil esterlerinin (FAME) oluşturulmasında (AOAC 996.01) metodu kullanılmıştır (Satchithanandam ve ark., 2001). Eter ekstraksiyon yöntemi ile elde edilen $0,1 \mathrm{~g}$ yağ, $10 \mathrm{ml}$ n-hekzan ile çalkalanmış, $0,5 \mathrm{ml} 2 \mathrm{~N}$ metanollü potasyum hidroksit çözeltisi ilave edilerek tekrar karıştırılmıştır. 1-2 saat karanlık ortamda bekletildikten sonra üst fazdan $1 \mu \mathrm{L}$ gaz kromatografisine enjekte edilmiştir. Yağ asidi kompozisyonu; Shimadzu marka gaz kromatografi (model QP2010 Plus) cihazında alev iyonizasyon dedektör (FID) ve Restek RTX-2330 kapiler kolon (60 m, 0,25 mm i,d, 0,1 $\mu \mathrm{m}$ film kalınlı̆̆ı, Bellefonte, PA (USA) kullanılarak analiz edilmiştir. Kolon firını sıcaklığ $100^{\circ} \mathrm{C}$ 'de $3 \mathrm{dk}$ tutulduktan sonra, dakikada $4^{\circ} \mathrm{C}$ artışla $240^{\circ} \mathrm{C}$ 'ye ulaştırılacak ve son sicaklık derecesinde $18 \mathrm{dk}$ bekleyecek şekilde programlanmıştır. Enjeksiyon sicaklığ $250^{\circ} \mathrm{C}$, dedektör sıcaklığ 1 ise $255^{\circ} \mathrm{C}$ 'ye ayarlanmıştır. Taşıyıcı gaz olarak helyum kullanılmış ve akış hızı 0,64 ml/dk olacak şekilde ayarlanmıştır. Enjeksiyon split oranı 1:80 olarak ayarlanmıştır. GC-FID sisteminin kontrolü için Lab Solution bilgisayar programı ve standart olarak FAME mix 37 standardı (Supelco) kullanılmıştır. FAME pikleri; alıkonma zamanları ve standartta belirtilen zincir uzunlukları kıyaslanarak teşhis edilmiştir.

$\mathrm{Bu}$ çalı̧̧mada verilen yağ asitlerinin uluslararası kısaltmaları verilmiştir; Myristic acid (C14:0), palmitic acid (C16:0), stearic acid (C18:0), oleic acid $(\mathrm{C} 18: \ln 9 \mathrm{c})$, linoleic acid (C18:2n6c), cis-11-eicosenoic acid (C20:1), linolenic acid (C18:3n3), erucic acid (C22:1n9), behenic acid (C22:0), cis-4,7,10,13,16,19-docosahexaenoic acid (C22:6n3) DHA.

Araştırma tesadüf parselleri faktöriyel deneme planına göre yürütülmüştür (3 tür, 2 yetiştirme sistemi, 2 karkas parçası, 2 tekerrür). Elde edilen verileri varyans analiz yöntemi kullanılarak değerlendirilmiş̧ir. Aralarında farklılık bulunan grupların belirlenmesinde Duncan çoklu karşılaşıırma testi kullanılmıştır (Özdamar, 2002).

\section{Bulgular ve Tartışma}

Türlere göre ham yağ oran1, C18:2n6c, C18:3n3 ve C20:1 keklik, C14:0 beç tavuğu, C22:6n3 sülün, $\mathrm{C} 18: 0$ ve $\mathrm{C} 22: \ln 9$ sülün ve beç tavuğu, $\mathrm{C} 18: \ln 9 \mathrm{c}$ ise keklik ve sülün etinde daha yüksek belirlenmiştir $(P<0,05)$. (Çizelge 1 ve Çizelge 2). Farklı türlerdeki hayvanların etleri kokusu, yapısı, içeriği ve kompozisyonu ile karakterize edilir ve bu durum önemli bir faktör olarak da kabul edilir (Chernukha, 2011). Belirli bir ürünün besin değeri karakterize edildiğinde yağ ve yağ bileşimi çok önemli olmaktadır (Lisitsyn, 2013). Bu çalışmada besin madde kompozisyonu içerisinde sadece ham yağ oranı farklılık göstermiş olup, keklik etinde bu oran daha yüksek bulunmuştur. Yağ asitleri içeriği bakımından ise yağ asitleri türler arasında farklılık göstermiştir. Türler arasında karşılaştırmalı yapılan diğer çalışmalarda ise (koyun, domuz, sığır, hindi, at, etlik piliç, sülün, kaz, keklik, beç tavuğu,) besin madde ve yağ asitleri içeriği yönünden farklılıklar tespit edilmiștir (Enser ve ark., 1996; Irina, 2011; Lisutsyn ve ark., 2013; Strakova ve ark., 2011; Vitula ve ark., 2011; Wood ve ark., 2008). Yetiştirme sisteminin besin madde kompozisyonu ve yağ asitleri üzerine etkisi önemsiz olmuştur $(\mathrm{P}>0,05)$. Çizelge 1 
ve Çizelge 2'de verilmiștir. Kanatlılarda besin madde kompozisyonu ve yağ asitleri üzerine etkili olan genotip ile birlikte en önemli faktör yetiştirme sistemi görülmektedir. Serbest gezinmeli yetiştirme sisteminin etkisi kesim yaşı, fiziksel aktivite ve dış ortamdaki yemlere ulaşabilmesine bağlıdır (Bogosavljevic-Boskovic ve ark., 2012). Yetiştirme sisteminin seçimi kesim, karkas ve et kalite özelliklerini etkileyen genetik olmayan faktörler içerisinde çok önemli bir parametre (Meluzzi ve ark., 2009) olmasına rağmen araștırmada besin madde ve yağ asitleri üzerine etkisi önemsiz bulunmuştur. Son yıllarda kanatlı eti endüstrisindeki hayvan refahı sorunlarına ve alternatif sistemlerin karşılaştırmasına geniş yer verilmektedir. Kanatlı hayvan yetiștiriciliğinde entansif üretim sistemine alternatif olarak geliştirilen sistemlerden ve alternatif türlerden elde edilen ürünlere tüketici talebi gün geçtikçe artmaktadır (Aksoy ve ark, 2010; Brown ve ark., 2008). Bu artış öncelikle daha iyi hayvan refahı algısından kaynaklanmaktadır. Dünyada alternatif türler ve yetiştirme sistemleri konusunda yeni girişimler bulunmakla birlikte, gerek hayvan refahı gerekse özel lezzete sahip ürünler konusunda kamuoyunda bir eğilim vardır (Quaresma ve ark., 2016). Bu çalışmada elde edilen besin madde ve yă asitleri değerleri yetiştirme sistemleri açısından farklılık oluşturmasa da özellikle serbest üretim sistemi açısından düşünüldüğünde, bu tür bir üretim sisteminin hayvanlara sadece sağlıklı bir çevre, iyi bir refah durumu değil, aynı zamanda beslenme ihtiyaçlarına da yeterli bir yanıt verdiği belirlenmiştir. Karkas içerisinde ekonomik açıdan en değerli kısım göğüs etidir ve bu kısmın özellikleri ticari firmaları yakından ilgilendirmektedir (Aksoy ve ark, 2010). Çalışmalarda en çok ele alınan karkas parçaları göğüs ve but etidir. Kuru madde, ham protein, C14:0, C16:0 ve C18:0 göğüs etinde, ham yağ, C18:1n9c, C18:2n6c, $\mathrm{C} 18: 3 \mathrm{n} 3, \mathrm{C} 22: 1 \mathrm{n} 9$ ve $\mathrm{C} 22: 6 \mathrm{n} 3$ oranlar1 but etinde daha yüksek bulunmuştur ( $\mathrm{P}<0,05$; Çizelge 1 ve Çizelge 2$)$. Kaslar arasındaki kas lifi tipindeki farklılıklar besin madde kompozisyonu ve yağ asidi bileşimindeki farklılıklara yansımaktadır (Wood ve ark., 2003). Hayvan türlerinin ve karkaslarının yağ içeriği üzerine yağ asitleri kompozisyonun önemli bir etkisi vardır. Bu etki farklı nötral lipid ve fosfolipid yapısından kaynaklanmaktadır (Wood ve ark., 2008). Belirtilen literatür bilgilerine paralel olarak araştırmadan elde edilen sonuçlarının kesiştiği görülmektedir (Enser ve ark., 1996; Quaresma ve ark., 2016). Diğer hayvan türlerinin farklı karkas dokularında da yağ asitleri içeriğinin değişim gösterdiğini bildirmişlerdir. Sülünler, yabani hindi, bıldırcın, beç tavuğu, keklik ve sakarmeke (su tavuğu, Fulica atra) üzerine yapılan değişik çalışmalarda araştırma sonuçlarına benzer olarak göğüs eti protein oranı yüksek, yağ oranı ise daha düşük bulunmuştur (Hascik ve ark., 2006; Kwiecien ve ark., 2015; Tucak ve ark., 2008; vecerek ve ark., 2005; Vitula ve ark., 2011). Yabani sülün, çiftlik sülünü, sakarmeke (Fulica atra), etlik piliç, kaz ve yabani ördek üzerine yapılan çalışmalarda hem türler hem de göğüs ve but eti örnekleri arasında besin madde ve yağ asitleri kompozisyonu bakımından farklılıklar belirlenmiştir (Geldenhuys ve ark., 2013; Nuernberg ve ark., 2011; Strakova ve ark., 2011).

Çizelge 1. Keklik, sülün ve beç tavuğunda besin madde kompozisyonu

Table 1. Nutrient composition in partridge, pheasant and guinea fowl

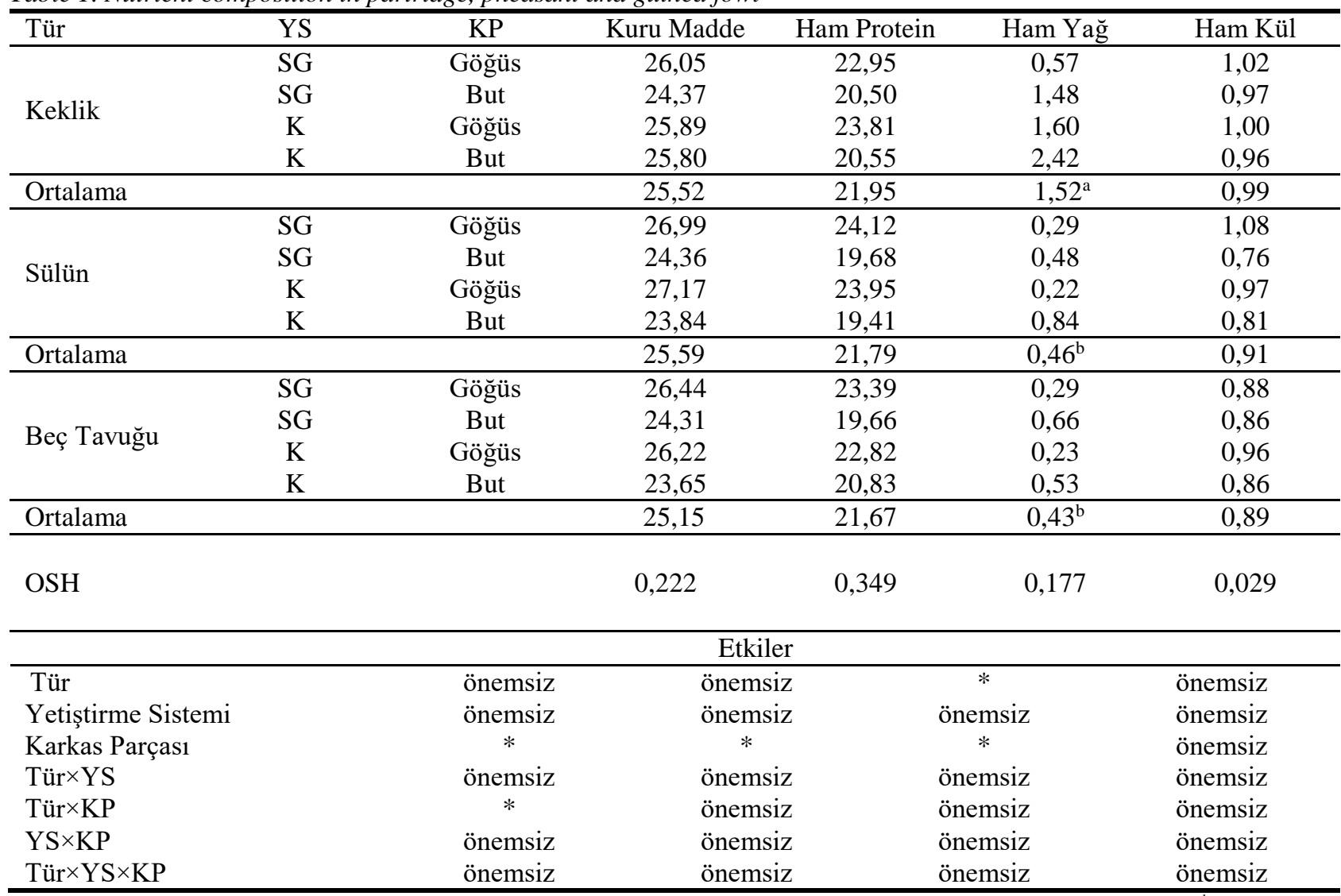

YS: yetiștirme Sistemi,KP: Karkas Parçası,SG: Serbest Gezinmeli, K: Kapalı, OSH : Ortalama Standart Hata, önemsiz: P>0,05 *, P<0,05 a,b: Aynı sütunda farklı üstel harflerle ifade edilen değerler istatistiksel olarak birbirinden farklıdır $(\mathrm{P}<0,05)$ 
Çizelge 2. Sülün, keklik ve beç tavuğunda bazı yağ asitleri içeriği

Table 2. Some fatty acids content in pheasant, partridge and guinea fowl

\begin{tabular}{|c|c|c|c|c|c|c|c|c|c|c|c|c|}
\hline Tür & YS & $\mathrm{KP}$ & $\begin{array}{c}\text { C14: } \\
0\end{array}$ & $\begin{array}{c}\text { C16: } \\
0\end{array}$ & $\begin{array}{c}\text { C18: } \\
0\end{array}$ & $\begin{array}{l}\text { C18: } \\
\text { 1n9c }\end{array}$ & $\begin{array}{l}\text { C18: } \\
2 \mathrm{n} 6 \mathrm{c}\end{array}$ & $\begin{array}{l}\text { C18: } \\
\text { 3n3 }\end{array}$ & $\begin{array}{c}\text { C20: } \\
1\end{array}$ & $\begin{array}{c}\text { C22: } \\
0\end{array}$ & $\begin{array}{c}\text { C22: } \\
\text { 1n9 }\end{array}$ & $\begin{array}{l}\text { C22: } \\
\text { 6n3 }\end{array}$ \\
\hline \multirow{4}{*}{ KL } & SG & Göğüs & 1,00 & 29,34 & 20,31 & 20,18 & 18,45 & 0,35 & 2,02 & 2,10 & 0,64 & 0,12 \\
\hline & SG & But & 0,68 & 22,24 & 12,14 & 8,57 & 28,97 & 0,39 & 1,11 & 0,45 & 2,15 & 0,47 \\
\hline & $\mathrm{K}$ & Göğüs & 0,86 & 26,60 & 16,60 & 25,94 & 22,80 & 0,32 & 0,87 & 0,69 & 1,46 & 0,22 \\
\hline & $\mathrm{K}$ & But & 0,71 & 25,79 & 11,41 & 29,59 & 29,73 & 0,36 & 1,15 & 0,56 & 1,20 & 0,17 \\
\hline \multicolumn{3}{|c|}{ Ortalama } & $0,82^{\mathrm{b}}$ & 25,14 & $15,11^{\mathrm{b}}$ & $26,07^{a}$ & $24,99^{\mathrm{a}}$ & $0,36^{\mathrm{a}}$ & $1,29^{\mathrm{a}}$ & 0,97 & $1,36^{\mathrm{b}}$ & $0,25^{\mathrm{c}}$ \\
\hline \multirow{4}{*}{ SL } & SG & Göğüs & 1,06 & 29,33 & 24,05 & 20,43 & 14,08 & 0,19 & 0,61 & 1,01 & 2,29 & 0,40 \\
\hline & SG & But & 0,80 & 23,88 & 15,93 & 27,07 & 20,28 & 0,29 & 0,65 & 0,66 & 3,91 & 0,70 \\
\hline & $\mathrm{K}$ & Göğüs & 0,91 & 29,53 & 20,34 & 25,02 & 14,11 & 0,24 & 0,38 & 0,32 & 2,29 & 0,41 \\
\hline & $\mathrm{K}$ & But & 0,73 & 24,59 & 16,77 & 28,06 & 19,12 & 0,27 & 0,39 & 0,58 & 4,24 & 0,61 \\
\hline \multicolumn{3}{|c|}{ Ortalama } & $0,88^{\mathrm{b}}$ & 26,83 & $19,28^{\mathrm{a}}$ & $25,15^{\mathrm{a}}$ & $16,90^{c}$ & $0,25^{\mathrm{b}}$ & $0,51^{\mathrm{b}}$ & 0,65 & $3,18^{\mathrm{a}}$ & $0,53^{\mathrm{a}}$ \\
\hline \multirow{4}{*}{ BT } & SG & Göğüs & 0,91 & 31,09 & 23,26 & 17,20 & 16,13 & 0,19 & 0,47 & 0,86 & 2,55 & 0,29 \\
\hline & SG & But & 0,89 & 24,56 & 15,55 & 25,16 & 24,84 & 0,27 & 0,68 & 0,53 & 3,08 & 0,37 \\
\hline & $\mathrm{K}$ & Göğüs & 1,34 & 27,54 & 17,98 & 17,61 & 18,73 & 0,15 & 0,58 & 0,35 & 2,24 & 0,34 \\
\hline & $\mathrm{K}$ & But & 0,90 & 24,87 & 17,88 & 18,99 & 27,19 & 0,28 & 0,73 & 0,91 & 3,86 & 0,44 \\
\hline \multicolumn{3}{|c|}{ Ortalama } & $1,01^{\mathrm{a}}$ & 27,01 & $18,67^{\mathrm{a}}$ & $19,74^{\mathrm{b}}$ & $21,72^{\mathrm{b}}$ & $0,23^{\mathrm{b}}$ & $0,62^{\mathrm{b}}$ & 0,64 & $2,93^{\mathrm{a}}$ & $0,37^{\mathrm{b}}$ \\
\hline \multicolumn{3}{|c|}{$\mathrm{OSH}$} & 0,034 & 0,647 & 0,825 & 0,868 & 1,063 & 0,019 & 0,132 & 0,161 & 0,206 & 0,034 \\
\hline \multicolumn{13}{|c|}{ Etkiler } \\
\hline \multicolumn{3}{|c|}{ Tür } & $*$ & önsz & $*$ & $*$ & $*$ & $*$ & $*$ & önsz & $*$ & $*$ \\
\hline \multicolumn{3}{|c|}{ Yetiştirme Sistemi } & önsz & önsz & önsz & önsz & önsz & önsz & önsz & önsz & önsz & önsz \\
\hline \multicolumn{3}{|c|}{ Karkas Parçası } & $*$ & $*$ & $*$ & $*$ & $*$ & $*$ & önsz & önsz & $*$ & $*$ \\
\hline \multicolumn{3}{|c|}{ Tür $\times Y S$} & $*$ & önsz & önsz & $*$ & önsz & önsz & önsz & önsz & önsz & önsz \\
\hline \multicolumn{3}{|c|}{ Tür $\times$ KP } & önsz & önsz & önsz & önsz & önsz & önsz & önsz & önsz & $*$ & önsz \\
\hline \multicolumn{3}{|c|}{$\mathrm{YS} \times \mathrm{KP}$} & önsz & önsz & $*$ & $*$ & önsz & önsz & önsz & önsz & önsz & önsz \\
\hline \multicolumn{3}{|c|}{ Tür $\times Y S \times K P$} & . & önsz & önsz & önsz & önsz & önsz & önsz & önsz & $*$ & önsz \\
\hline
\end{tabular}

KL: Keklik, SL: Sülün, BT: Beç tavuğu, YS: Yetiştirme sistemi, KP: Karkas parçası, SG: Serbest gezinmeli, K: Kapalı, OSH: Ortalama standart hata, önsz: $\mathrm{P}>0,05, *: \mathrm{P}<0,05$, a,b,c: Aynı sütunda farklı üstel harflerle ifade edilen değerler istatistiksel olarak birbirinden farklıdır $(\mathrm{P}<0,05)$

Tür×yetiştirme sistemi interaksiyonunun C14:0 ve C18:1n9c, yetiştirme sistemi $\times$ karkas parçası interaksiyonunun $\mathrm{C} 18: 0$ ve $\mathrm{C} 18: 1 \mathrm{n} 9 \mathrm{c}$, tür $\times$ yetiştirme sistemi $\times$ karkas parçası interaksiyonunun ise C14:0 ve C22:1n9 yağ asitleri üzerine etkisi önemli bulunmuştur $(\mathrm{P}<0,05)$. Çizelge 2. Tür $\times$ karkas parçası interaksiyonunun kuru madde ve C22:1n9 yağ asiti üzerine etkisinin önemli olduğu tespit edilmiştir $(\mathrm{P}<0,05)$. (Çizelge 1 ve Çizelge 2$)$.

\section{Sonuç}

Farklı türlerdeki hayvanlardan elde edilen etler spesifik bileşim, yapı ve koku ile karakterize olmaktadır. Fakat et hammaddesi türlerinin kökenini basit fiziksel, kimyasal ve duyusal analiz yöntemleriyle tanımlamak zordur (Irina, 2011). Elde edilen veriler besin madde kompozisyonu ve yağ asitleri bakımından tür, yetiştirme sistemi ve karkas parçaları karşılaştırmasını ortaya koymuştur. Göğüs ve but eti içeriği bir çok özellik yönünden farklılık göstermiştir. Türler arasında da özellikle yağ asitleri bakımından farklılıklar görülmüştür. Yetiştirme sistemleri arasında farklılık oluşmaması, özellikle tüketiciler tarafından tercih edilmesi ve hayvan refahı açısından serbest gezinmeli üretim için olumlu düşünülebilir. Çalışma sonuçları, besin madde kompozisyonu ve yağ asidi dengesini düzenleyen faydalı fonksiyonel özelliklere sahip et ürünlerinin geliştirilmesi ve üretilmesi için de kaynak oluşturmaktadır.

\section{Teşekkür}

Araştırmayı 6602b-ZF/16-15 ve 6602b-ZF/16-46 nolu projelerle desteklediklerinden dolayı, Yozgat Bozok Üniversitesi BAP birimine teşekkür ederiz.

\section{Kaynaklar}

Aksoy, T., Önenç, A., Narinç, D., Cürek, D.İ., Yapıcı, N., Baylan, D., 2010. Farklı kesim ağırlığı, genotip ve cinsiyetin etlik piliçlerde göğüs eti duyusal özelliklerine etkisi. Journal of Agricultural Faculty of Uludag University 24(2): 103-113.

Alva, V.I.A., Quintana, L.J.A., Gonzales-Rebeles, I.C., Gonzalez ,A.M., 2015. Effect of photoperiod on the production of chukar partridges (Alectoris chukar). International Journal of Poultry Science 14 (12), 657663.

Bogosavljevic-Boskovic, S., Rakonjac, A., Doskovıc, V., Petrovic M. D., 2012. Broiler rearing systems: a review of major fattening results and meat quality traits. World's Poultry Science Journal 68: 217-228.

Boz, M.A., Sarıca, M., Yamak, U.S., 2017. Production traits of artificially and naturally hatched geese in intensive and free-range systems - II: slaughter, carcass and meat quality traits. British Poultry Science 58(2):166176.DOI: 10.1080/00071668.2016.1261998.

Brown, S.N., Nute, G.R., Baker, A., Hughes, S.I., Warriss, P.D., 2008. Aspects of meat and eating quality of broiler chickens reared under standard, maize-fed, free-range or organic systems. British Poultry Science 49(2): 118-124. 
Castellini, C., Mugnai, C., Dal Bosco, A., 2002. Effect of organic production system on broiler carcass and meat quality. Meat Science 60: 219-225.

Chernukha, I., 2011. Comparative study of meat composition from various animal species. Tehnologija Mesa 52(1): 167-171.

Du, M., Ahn, D. U., 2002. Effect of dietary conjugated linoletic acid on the growth rate of live birds and on the abdominal fat content and quality of broiler meat Poultry Science 81: 428-433.

Enser, M., Hallett, K., Hewitt, B., Fursey, G.A.J., Wood, J.D. 1996. Fatty acid content and composition of English beef, lamb and pork at retail.Meat Science 42: 443-456.

Geldenhuys, G., Hoffman, L.C., Muller, N., 2013. The effect of season, sex, and portion on the carcass characteristics, $\mathrm{pH}$, color, and proximate composition of Egyptian Goose (Alopochen aegyptiacus) meat. Poultry Science 92: 3283-3291. DOI:10.3382/ps.2013-03443.

Gökalp, H. Y., Kaya, M., Tülek, Y., Zorba, Ö., 2010. Et ve ürünlerinde kalite kontrolü ve laboratuvar uygulama kılavuzu. (V. Baskı), Atatürk Üniv. Yayınları, Yayın No: 751, Ziraat Fak. Yayın No: 318, Ders Kitapları Seri No:69, Atatürk Üniversitesi, Ofset Tesisi, Erzurum.

Hascik, P., Gasparik J., Kulisek V., Vladorova D., 2006 Nutritional quality of black coot (Fulica atra) meat. Maso 17(5):16-18

Irina, C., 2011. Comparative study of meat composition from various animal species. Tehnologija mesa 52 (1): 167-171.

Kwiecien, M., Kasperek, K., Grela, E., JeżewskaWitkowska, G., 2015. Effect of caponization on the production performance, slaughter yield and fatty acid profile of muscles of Greenleg Partridge cocks. J. Food Sci. Technol. 52(11): 7227-7235. DOI 10.1007/s13197015-1856-6.

Lisitsyn, A. B., Chernukha, I. M., Ivankin, A. N., 2013. Comparative study of fatty acid composition of meat material from various animal species. Scientific Journal of Animal Science 2(5): 124-131.

Meluzzi, A., Sirri, F., Castellini, C., Roncarati, A., Melloti, P., Franchini, A., 2009. Influence of genotype and feeding on chemical composition of organic chicken meat. Italian Journal of Animal Science 8: 766-768.

Nuernberg, K., Slamecka, J., Mojto, J., Gasparik, J., Nuernberg, G., 2011. Muscle fat composition of pheasants (Phasianus colchicus), wild ducks (Anas platyrhynchos) and black coots (Fulica atra). Eur. J. Wildl. Res. 57: 795-803. DOI 10.1007/s10344-0100489-3.

Özdamar, K. 2002. Paket programlar ile istatistiksel veri analizi I., 4. baskı, Kaan Kitabevi, Eskişehir.

Quaresma, M.A.G., Pimentel, F.B., Ribeiro, A.P., Ferreira, J.D., Alves, S.P., Rocha, I., Bessa, R.J.B., Oliveira, M.B.P.P., 2016. Lipid and protein quality of common pheasant (Phasianus colchicus) reared in semiextensive conditions. Journal of Food Composition and Analysis 46: 88-95.
Sarıca, M., Karaçay, N., Camci, Ö., 1999. Slaughter age and carcass traits of pheasants. Arch. Geflügelk, 63(4): 182-184.

Sarıca, M., Camcı, Ö., Selçuk, E., 2003. Bıldırcın, sülün, keklik, etçi güvercin, beç tavuğu ve devekuşu yetiștiriciliği. OMÜ Ziraat Fakültesi Baskı Ünitesi, 3. Bask1, Ders Kitab1 No:4, Samsun.

Satchithanandam, S., Fritsche, J., Rader, J. I., 2001. Extension of AOAC Official Method 996.01 to the Analysis of Standard Reference Material (SRM) 1846 and Infant Formulas. Journal of AOAC International 84: 805-813.

Solokowicz, Z., Krawczyk, J., Swiatkiewicz, S., 2016. Quality of poultry meat from native chicken breeds - a review. Ann. Anim. Sci., 16(2): 347-368. DOI: 10.1515/aoas-2016-0004.

Strakova, E., Suchy, P., Karaskova, K., Jambor, M., Navratil, P., 2011. Comparison of nutritional values of pheasant and broiler chicken meats. Acta Vet. Brno, 80: 373-377; DOI:10.2754/avb201180040373

Tucak, Z., Skrivanko, M., Posavcevic, S., Periskic, M., Boskovic, I., Jumic, V., 2008. The influence of keeping pheasants in captivity vs. nature on the biological value of meat and its use in human nutrition. Coll. Antropol. 32(3): 959-962.

Uçar, A., 2014. Sülünlerde yumurta verimi, yaş ve kuluçka özellikleri arasındaki ilișkiler. Yüksek Lisans Tezi, OMÜ, Fen Bilimleri Enstitüsü, SAMSUN.

Vecerek, V., Suchy, P., Strakova, E., Vitula F., Mikundova, M., 2005. Variation in the chemical composition of muscles in young pheasants during their growth. Arch. Anim. Breed. 48(3): 290-298.

Vitula, F., Suchy, P., Strakova, E., Karaskova, K., Zapletal, D., Kroupa, L., 2011. Energy value of meat in selected species of feathered game. Acta Vet. Brno. 80: 197-202. DOI:10.2754/avb201180020197

Wood, J.D., Richardson, R.I., Nute, G.R., Fisher, A.V., Campo, M.M., Kasapidou, E., Sheard, P.R., Enser, M., 2003. Effects of fatty acids on meat quality: a review. Meat Science 66: 21-32.

Wood, J. D., Enser, M., Fisher, A. V., Nute, G. R., Sheard, P. R., Richardson, R.I., Hughes, S. I., Whittington, F. M., 2008. Fat deposition, fatty acid composition and meat quality: A review. Meat Science 78: 343-358.

Yamak, U. S., Sarıca, M., Boz, M. A., Uçar, A., 2016. The effect of production system (barn and freerange), slaughtering age and gender on carcass traits and meat quality of partridges (Alectoris chukar). British Poultry Science57(2):185-192.DOI: 10.1080/00071668.2016.1144920.

Yetişir, R., Karakaya, M., İlhan, F., Yılmaz, F. T., Özalp, B., 2008. Tüketici tercihini etkileyen bazı piliç eti kalite özellikleri üzerine farklı aydınlatma programları ile cinsiyetin etkileri. Hayvansal Üretim 49(1): 20-28.

Yıldırım, A., 2009. Etlik beç tavuklarının beslenmesi. Hayvansal Üretim 50(2): 60-65. 